\title{
Penerapan Pembelajaran Tipe Jigsaw Pada Mata Pelajaran Sejarah Untuk Meningkatkan Aktivitas Belajar Dan Hasil Belajar Siswa Kelas XI IPS 1 Di Sekolah Menengah Atas Negeri 1 Muaro Jambi
}

\author{
Novrita Suryani \\ Sekolah Menengah Atas Negeri 1 Muaro Jambi, Indonesia
}

\begin{abstract}
This study aim to improve students learning result and students learning activity in History studies fro students in class XI IPS 1 SMAN Negeri 1 Muaro Jambi in 2017/2018 academic year by implementing the Jigsaw model. The data collected through observation, documentation and interview. The result of study display that are: 1) the Jigsaw model is able to improve learning process; 2) student's learning result improves from $64 \%$ to $71 \%$ in cycle I and to $85 \%$ in cycle II; 3) the Jigsaw model drives students willing for learning; 4) the responsibility of students improve; 5) and the learning history become fun and meaningful.
\end{abstract}

Keywords: students' learning activity and result, Jigsaw model, history studies

\section{Pendahuluan}

Undang-Undang Nomor 20 Tahun 2003 tentang Sistem Pendidikan Nasional menyebutkan bahwa kurikulum adalah seperangkat rencana dan pengaturan mengenai tujuan, isi, dan bahan pelajaran serta cara yang digunakan sebagai pedoman penyelenggaraan kegiatan pembelajaran untuk mencapai tujuan pendidikan tertentu. Berdasarkan pengertian tersebut, ada dua dimensi kurikulum, yang pertama adalah rencana dan pengaturan mengenai tujuan, isi, dan bahan pelajaran, sedangkan yang kedua adalah cara yang digunakan untuk kegiatan pembelajaran.Kurikulum 2013 yang diberlakukan mulai tahun ajaran 2013/2014 memenuhi kedua dimensi tersebut. berikut:

Kurikulum 2013 dikembangkan dengan penyempurnaan pola pikir sebagai

1) pola pembelajaran yang berpusat pada guru menjadi pembelajaran berpusat pada peserta didik. Peserta didik harus memiliki pilihan-pilihan terhadap materi yang dipelajari untuk memiliki kompetensi yang sama;

2) pola pembelajaran satu arah (interaksi guru-peserta didik) menjadi pembelajaran interaktif (interaktif guru-peserta didik-masyarakatlingkungan alam, sumber/media lainnya);

3) pola pembelajaran terisolasi menjadi pembelajaran secara jejaring (peserta didik dapat menimba ilmu dari siapa saja dan dari mana saja yang dapat dihubungi serta diperoleh melalui internet); 
4) pola pembelajaran pasif menjadi pembelajaran aktif-mencari (pembelajaran siswa aktif mencari semakin diperkuat dengan model pembelajaran pendekatan sains);

5) pola belajar sendiri menjadi belajar kelompok (berbasis tim);

6) pola pembelajaran alat tunggal menjadi pembelajaran berbasis alat multimedia;

7) pola pembelajaran berbasis massal menjadi kebutuhan pelanggan (users) dengan memperkuat pengembangan potensi khusus yang dimiliki setiap peserta didik;

8) pola pembelajaran ilmu pengetahuan tunggal (monodiscipline) menjadi pembelajaran ilmu pengetahuan jamak (multidisciplines); dan

9) pola pembelajaran pasif menjadi pembelajaran kritis.

Digulirkannya kurikulum 2013 secara yuridis berdasarkan Permendiknas nomor 65 tahun 2013, mata pelajaran sejarah mengalami penambahan jam yaitu 2 jam pembelajaran sejarah wajib dan 3 jam pelajaran sejarah peminggu, dari kerangka dasar ini guru sejarah harus dapat menyiasati penbelajaran sejarah dengan tidak mengubah, hakikat pelajaran sejarah. Pengajaran sejarah merupakan suatu proses yang mengandung serangkaian kegiatan antara guru dan siswa secara timbal balik yang berlangsung dalam situasi edukatif dan kondusif untuk mencapai tujuan yang diharapkan.

Melalui proses pengajaran siswa dapat tumbuh menuju ke dewasaan yang optimal, karena dalam pengajaran dapat mengembangkan empat kemampuan (kompetensi) antara lain: K1 (kompetensi Religius), K2 (kompetensi Sosial), K3 (kompetensi pengetahuan), K4 (kompetensi ketrampilan). Siswa mengalami permasalahan dalam pemahaman fakta, kosnsep, prinsip dalam mata pelajaran sejaran.upaya yang dilakukan guru untuk meningkatkan pemahaman siswa terhadap pembelajaran sejarah melalui pendekatan saintifik. Alternatif penelitian tindakan kelas ini sebagai upaya untuk pemecahan masalah dalam mengatasi kebekuan dan kebuntuan pengajaran sejarah dalam \pemahaman siswa akan fakta, konsep dan prinsip sejarah.

Belajar merupakan proses yang sangat penting dan mempunyai peranan utama dalam peningkatan keberhasilan siswa. Di mana hasil belajar siswa yang diharapkan baik oleh guru maupun orang tua adalah peningkatan seluruh potensi yang dimiliki oleh siswa, seperti kognitif, afektif, dan psikomotorik. Karena kegiatan pembelajaran itu sendiri adalah proses latihan terhadap seluruh potensi yang dimiliki oleh siswa. Maka sewajarnyalah seorang siswa turut berpartisifasi aktif dalam kegiatan belajar, sedangkan guru hanya berperan sebagai mediator, moderator, fasilitator dan organisator.

Hasil belajar yang diharapkan kadang kala dapat mencapai tujuan yang sudah ditetapkan baik di dalam standar kompetensi lulusan, maupun criteria ketuntasan minimal, tetapi hanya sebagian kecil saja yang dapat mencapainya. Hal ini terjadi karena sebagian besar siswa masih beranggapan bahwa hasil belajar lebih penting, sedangkan proses belajar diabaikan.Oleh karena itu apabila hasil belajar yang diperoleh menurun maka akan berpengaruh pada turunnya tingkat aktivitas belajar siswa. 
Terjadinya ketidak sesuai antara proses belajar dengan hasil belajar yang diharapkan siswa karena dipengaruhi kurangnya sarana sumber belajar yang dimiliki siswa. Siswa belum dapat memahami model pembelajaran kooperatif Jigsaw seutuhnya serta belum dapat melaksanakan proses pembelajaran melalui diskusi kelompok. Apabila guru tidak tanggap terhadap gejala-gejala penyimpangan yang terjadi pada siswa, maka berakibat semakin menurunnya tingkat aktivitas belajar dan hasil belajar siswa. Selain itu seluruh potensi yang dimiliki oleh siswa juga tidak dapat tumbuh dan berkembang dengan baik. Terhadap faktor-faktor yang dapat menghambat aktivitas belajar siswa hendaknya guru segera mengadakan perbaikan perencanaan pembelajaran yang berkaitan dengan komponen seperti tujuan pembelajaran, materi pembelajaran, model pembelajaran, tipe pembelajaran, metode pembelajaran, serta sumber belajar dan alat penilaian.

Berdasarkan rumusan masalah di atas, maka tujuan dilaksanakan penelitian tindakan kelas ini adalah untuk mengatahui bagaimanakah penerapan model pembelajaran tipe jigsaw pada mata pelajaran sejarah dapat meningkatkan aktivitas belajar dan hasil belajar siswa kelas xi ips 1 di sma negeri 1 muaro jambi tahun pelajaran 2017/2018 dan sebagai tolak ukur dalam menentukan tingkat kelulusan dari penerapan model kooperatif jigsaw untuk menganalisis kehidupan sosial,ekonomi,budaya,militer dan pendidikan di indonesia pada masa pendudukan jepang,dapat meningkatkan aktivitas belajar dan hasil belajar siswa kelas xi ips 1 di sma negeri 1 muaro jambi tahun pelajaran 2017/2018.

\section{Belajar}

Skinner berpandangan bahwa belajar adalah suatu perilaku. Pada saat orang belajar maka responya menjadi lebih baik dan sebaliknya bila tidak belajar responnya menjadi menurun sedangkan menurut Gagne dalam Susanto, belajar adalah seperangkat proses kognitif yang mengubah sifat stimulasi limgkungan, melewati pengolahan informasi, menjadi kapasitas baru. (Ahmad Susanto, 2013, p.1)Sedangkan menurut kamus umum bahasa Indonesia belajar diartikan berusaha (berlatih) supaya mendapat suatu kepandaian. (Poerwodarminto, 1991, p.109)

\section{Hasil Belajar}

Menurut Anita Lie model pembelajaran kooperatif adalah suatu pendekatan yang berfokus pada penggunaan kelompok kecil agar dapat bekerjasama dalam memaksimalkan kondisi belajar untuk mencapai tujuan. (Lie Anita, 2010, p.8) Dimana model pembelajaran ini bertujuan untuk mengembangkan aspek keterampilan sosial sekaligus kognitif dan sikap siswa. Dalam model pembelajaran ini seorang guru berusaha menciptakan suasana belajar yang mendorong siswa saling membutuhkan dan saling ketergantungan positif.

Selain itu model pembelajaran ini bermanfaat untuk:

a. Meningkatkan kemampuan untuk bekerjasama dan bersosialisasi

b. Melatih kepekaan diri, empati melalui variasi perbedaan sikap dan perilaku selama bekerjasama.

c. Mengurangi rasa kecemasan dan menimbulkan rasa percaya diri

d. Meningkatkan motivasi belajar, harga diri dan sikap berperilaku positif, sehingga saling menghargai.

e. Meningkatkan prestasi belajar melalui presentasi akademik. 
Menurut Kamus Besar Bahasa Indonesia, istilah hasil belajar, terdapat dua unsur di dalamnya, yaitu unsur hasil dan unsur belajar. Hasil merupakan suatu hasil yang telah dicapai pebelajar dalam kegiatan belajarnya (dari yang telah dilakukan, dikerjakan, dan sebagainya. Dari pengertian ini, maka hasil belajar adalah penguasaan pengetahuan atau keterampilan yang dikembangkan oleh mata pelajaran, lajimnya ditunjukkan dengan nilai tes atau angka nilai yang diberikan oleh guru.

Menurut Nawawi keberhasilan murid dalam mempelajari materi pelajaran di sekolah yang dinyatakan dalam bentuk nilai atau skor dari hasil tes mengenai sejumlah pelajaran tertentu. (Hadari Nawawi, 1981, p.100) Pendapat lain dikemukakan oleh Sadly dalam Sumaryono memberikan penjelasan tentang hasil belajar sebagai hasil yang dicapai oleh tenaga atau daya kerja seseorang dalam waktu tertentu. (Agus Sumaryono, diakses hari Minggu 20 Januari 2019) sedangkan Marimba mengatakan bahwa hasil adalah kemampuan seseorang atau kelompok yang secara langsung dapat diukur. (A.D Marimba, 1978, p.143)

Menurut Nawawi berdasarkan tujuannya, hasil belajar dibagi menjadi tiga macam, yaitu: (Hadari Nawawi, 1981, p.127)

a. Hasil belajar yang berupa kemampuan keterampilan atau kecapakan di dalam melakukan atau mengerjakan suatu tugas, termasuk di dalamnya keterampilan menggunakan alat.

b. Hasil belajar yang berupa kemampuan penguasaan ilmu pengetahuan tentang apa yang dikerjakan.

c. Hasil belajar yang berupa perubahan sikap dan tingkah laku.

\section{Pengajaran Kooperatif}

Pengajaran kooperatif (cooperatif learning) memerlukan pendekatan pengajaran melalui penggunaan kelompok kecil siswa untuk bekerja sama dalam memaksimalkan kondisi belajar dalam mencapai tujuan belajar.

\section{Pengertian Pembelajaran Kooperatif}

Manusia memiliki derajat potensi, latar belakang histories, serta harapan masa depan yang berbeda-beda. Karena adanya perbedaan, manusia dapat silih asah (saling mencerdaskan). Pembelajaran kooperatif secara sadar menciptakan interaksi yang silih asah sehingga sumber belajar bagi siswa bukan hanya guru dan buku ajar tetapi juga sesama siswa.

Manusia adalah makhluk individual, berbeda satu dengan sama lain. Karena sifatnya yang individual maka manusia yang satu membutuhkan manusia lainnya sehingga sebagai konsekuensi logisnya manusia harus menjadi makhluk sosial, makhluk yang berinteraksi dengan sesamanya. Karena satu sama lain saling membutuhkan maka harus ada interaksi yang silih asih (saling menyayangi atau saling mencintai). Pembelajaran kooperatif merupakan pembelajaran yang secara sadar dan sengaja menciptakan interaksi yang saling mengasihi antar sesama siswa.

\section{Unsur Dasar Pembelajaran Kooperatif}

Pembelajaran kooperatif adalah suatu sistem yang di dalamnya terdapat elemen-elemen yang saling terkait. Adapun berbagai elemen dalam pembelajaran kooperatif adalah adanya: "(1) saling ketergantungan positif; (2) interaksi tatap 
muka; (3) akuntabilitas individual, dan (4) keterampilan untuk menjalin hubungan antar pribadi atau keterampilan sosial yang secara sengaja diajarkan, yang diuraikan sebagai berikut: (M Abdurrahman, \& Totok Bintoro, 2000, p.78-79)

a. Saling ketergantungan positif

Dalam pembelajaran kooperatif, guru menciptakan suasana yang mendorong agar siswa merasa saling membutuhkan. Hubungan yang saling membutuhan inilah yang dimaksud dengan saling memberikan motivasi ntuk meraih hasil belajar yang optimal. Saling ketergantungan tersebut dapat dicapai melalui: (a) saling ketergantungan pencapaian tujuan, (b) saling ketergantungan dalam menyelesaikan tugas, (c) saling ketergantungan bahan atau sumber, (d) saling ketergantungan peran, dan (e) saling ketergantungan hadiah.

b. Interaksi tatap muka

Interaksi tatap muka menuntut para siswa dalam kelompok dapat saling bertatap muka sehingga mereka dapat melakukan dialog, tidak hanya dengan guru, tetapi juga dengan sesama siswa. Interaksi semacam itu memungkinkan para siswa dapat saling menjadi sumber belajar sehingga sumber belajar lebih bervariasi. Interaksi semacam itu sangat penting karena ada siswa yang merasa lebih mudah belajar dari sesamanya.

c. Akuntabilitas individual

Pembelajaran kooperatif menampilkan wujudnya dalam belajar kelompok. Meskipun demikian, penilaian ditujukan untuk mengetahui penguasaan siswa terhadap materi pelajaran secara individual. Hasil penilaian secara individual tersebut selanjutnya disampaikan oleh guru kepada kelompok agar semua anggota kelompok mengetahui siapa anggota kelompok mengetahui siapa anggota yang memerluan bantuan dan siapa anggota kelompok yang dapat memberikan bantuan. Nilai kelompok didasarkan atas rata-rata hasil belajar semua anggotanya, dan karena itu tiap anggota kelompok harus memberikan urunan demi kemajuan kelompok. Penilaian kelompok secara individual inilah yang dimaksudkan dengan akuntabilitas individual.

d. Keterampilan menjalin hubungan antar pribadi

Dalam pembelajaran kooperatif keterampilan sosial seperti tenggang rasa, sikap sopan terhadap teman, mengkritik ide dan bukan mengkritifk teman, berani mempertahankan pikiran logis, tidak mendominasi orang lain, mandiri, dan berbagai sifat lain yang bermanfaat dalam menjalin hubungan antar pribadi (interpersonal relationship) tidak hanya diasumsikan tetapi secara sengaja diajarkan. Siswa yang tidak dapat menjalin hubungan antar pribadi tidak hanya memperoleh teguran dari guru tetapi juga dari sesama siswa.

\section{Peran Guru Dalam Pembelajaran Kooperatif}

Pembelajaran kooperatif menuntut guru untuk berperan relatif berbeda dari pembelajaran tradisional. Berbagai peran guru dalam pembelajaran kooperatif tersebut dapat dikemukan sebagai berikut ini.

a. Merumuskan tujuan pembelajaran. Ada dua tujuan pembelajaran yang perlu diperhatikan oleh guru, tujaun akademik (academic objectives) dan 
tujuan keterampilan bekerja sama (collaborative skill objectives). Tujuan akademik dirumuskan sesuai dengan taraf perkembangan siswa dan analisis tugas atau analisis konsep. Tujuan keterampilan bekerja sama meliputi keterampilan memimpin, berkomunikasi, mempercayai orang lain, dan mengelola konflik.

b. Menentukan jumlah anggota dalam kelompok belajar. Jumlah anggota dalam tiap kelompok belajar tidak boleh terlalu besar, biasanya 2 hingga 6 siswa. Ada 3 faktor yang menentukan jumlah anggota tiap kelompok belajar. Ketiga faktor tersebut adalah: (1) taraf kemampuan siswa, (2) ketersediaan bahan, dan (3) ketersediaan waktu. Jumlah anggota kelompok belajar hendaknya kecil agar tiap siswa aktif menjalin kerjasama menyelesaikan tugas. Ada 4 pertanyaan yang hendaknya dijawab oleh guru saat akan menempatkan siswa dalam kelompok. Keempat pertanyaan tersebut dapat dikemukakan sebagai berikut:

1) Pengelompokkan siswa secara homogen atau heterogen? Pengelompokkan siswa hendaknya heterogen. Keheterogenan kelompok mencakup jenis kelamin, ras, agama, (kalau mungkin), tingkat kemampuan (tinggi, sedang, rendah), dan sebagainya.

2) Bagaimana menempatkan siswa dalam kelompok? Ada dua jenis kelompok belajar kooperatif, yaitu (1) yang berorientasi bukan pada tugas (non-task-orientied), dan (2) yang berorientasi pada tugas (task oriented). Kelompok belajar kooperatif yang berorientasi bukan pada tugas tidak menuntut adanya pembagian tugas untuk tiap anggota kelompok. Kelompok belajar semacam ini tampak seperti pada saat siswa mengerjakan soal-soal Ilmu Pengetahuan Sosial berbentuk prosedur penyelesaian dan mencocokkan pendapatnya. Siswa bebas memilih teman atau ditentukan oleh guru. Kebebasan memilih teman sering menyebabkan kelompok belajar menjadi homogen sehingga tujuan belajar kooperatif tidak tercapai. Anggota tiap kelompok belajar hendaknya ditentukan secara acak oleh guru. Ada 3 teknik untuk menentukan anggota kelompok secara acak yang dapat digunakan oleh guru. Ketiga teknik tersebut dapat dikemukakan sebagai berikut.

a) Berdasarkan metode sosiometri. Melalui metode sosiometri guru dapat menentukan siswa yang tergolong disukai oleh banyak teman (bintang kelas) hingga yang paling tidak disukai atau tidak memiliki teman (terisolasi). Berdasarkan metode sosiometri tersebut guru menyusun kelompok-kelompok belajar yang di dalam tiap kelompok ada siswa yang tergolong banyak teman, yang tergolong biasa, dan yang terisolasi.

b) Berdasarkan kesamaan nomor. Jika jumlah siswa dalam kelas terdiri atas 30 siswa dan guru ingin membentuk 10 kelompok belajar yang dari 1 hingga 10. Selanjutnya, para siswa yang bernomor sama dikelompokkan sehingga terbentuklah 10 kelompok siswa dengan masing-masing beranggotakan 3 orang siswa yang memiliki karakteristik heterogen. 
c) Menggunakan teknik acak berstrata. Para siswa dalam kelas lebih dahulu dikelompokkan secara homogen atas dasar jenis kelamin dan atas dasar kemampuannya (tinggi, sedang, rendah), dan sebagainya. Setelah itu, secara acak siswa diambil dari kelompok homogen tersebut dan dimasukkan ke dalam sejumlah kelompok-kelompok belajar yang heterogen.

\section{Model Jigsaw}

Metode ini dikembangkan oleh Elliot Aronson dan kawan-kawannya dari Universitas Texas dan kemudian diadaptasi oleh Slavin dan kawan-kawannya. Melalui metode Jigsaw yaitu:

a. kelas dibagi menjadi beberapa tim yang anggotanya terdiri dari atau enam siswa dengan karakteristik yang heterogen.

b. Bahan akademik disajikan kepada siswa dalam bentuk teks; dan tiap siswa bertanggung jawab untuk mempelajari suatu bagian dari bahan akademik tersebut.

c. Pada anggota dari berbagai tim yang berbeda memiliki tanggung jawab untuk mempelajari suatu bagian akademik yang sama dan selanjutnya berkumpul untuk saling membantu mengkaji bagian bahan tersebut.

d. Kumpulan siswa semacam itu desebut "kelompok pakar" (expert group). Selanjutnya, para pakar siswa yang berada dalam kelompok pakar kembali ke kelompoknya semula (home teams) untuk mengajar anggota lain mengenai materi yang telah dipelajari dalam kelompok pakar.

e. Setelah diadakan pertemuan dan diskusi dalam "home teams", para siswa dievaluasi secara individual mengenai bahan yang telah dipelajari. Dalam metode Jigsaw versi Slavin. Individu atau tim yang memperoleh skor

\section{Metode} tinggi diberi penghargaan oleh guru.

Penelitian ini merupakan penelitian tindakan (action research), karena penelitian dilakukan untuk memecahkan masalah pembelajaran di kelas. Penelitian ini juga termasuk penelitian deskriptif, sebab menggambarkan bagaimana suatu teknik pembelajaran diterapkan dan bagaimana hasil yang diinginkan dapat dicapai. Kegiatan penelitian tindakan kelas ini ditujukan pada siswa-siswi kelas XI IPS 1 SMA Negeri 1 Muaro Jambi yang diawali dengan penyusunan proposal diajukan dan mendapatkan persetujuan, maka dilanjutkan dengan penyusunan instrument penelitian, pengumpulan data, analisis data, pembahasan dan penyusunan laporan hasil penelitian.

Tempat penelitian adalah tempat yang digunakan dalam melakukan penelitian untuk memperoleh data yang diinginkan. Penelitian ini bertempat di SMA Negeri 1 Muaro Jambi, Kec Jambi Luar Kota, Kab Muaro Jambi. Waktu penelitian adalah waktu berlangsungnya penelitian atau saat penelitian ini dilangsungkan. Penelitian ini dilaksanakan pada bulan Januari -Mei semester genap tahun pelajaran 2017/2018. Subyek penelitian adalah siswa-siswi Kelas XI IPS 1 tahun pelajaran 2017/2018 pada pokok bahasan mendeskripsikan perkembangan sejarah Indonesia pada masa praaksara.Sedangkan jumlah siswa yang terdapat dalam kelas XI IPS 1 adalah 17 orang perempuan dan 12 orang lakilaki. 
Instrumen yang digunakan dalam penelitian ini terdiri dari silabus, Rencana Pelajaran (RP), Lembar Kegiatan Siswa, dan Tes formatif. Analisis data dihitung dengan menggunakan statistik sederhana yaitu:

1. Untuk menilai ulangan atau tes formatif

Peneliti melakukan penjumlahan nilai yang diperoleh siswa, yang selanjutnya dibagi dengan jumlah siswa yang ada di kelas tersebut sehingga diperoleh rata-rata tes formatif dapat dirumuskan:

$$
\bar{X}=\frac{\sum X}{\sum N}
$$

$$
\begin{aligned}
\text { Dengan }: \bar{X}= & \text { Nilai rata-rata } \\
\Sigma \mathrm{X}= & \text { Jumlah semua nilai siswa } \\
& \Sigma \mathrm{N}=\text { Jumlah siswa }
\end{aligned}
$$

2. Untuk ketuntasan belajar

Ada dua kategori ketuntasan belajar yaitu secara perorangan dan secara klasikal. Berdasarkan petunjuk pelaksanaan belajar mengajar kurikulum 1994 (Depdikbud, 1994), yaitu seorang siswa telah tuntas belajar bila telah mencapai skor 75\% atau nilai 75, dan kelas disebut tuntas belajar bila di kelas tersebut terdapat $85 \%$ yang telah mencapai daya serap lebih dari atau sama dengan $65 \%$. Untuk menghitung persentase ketuntasan belajar digunakan rumus sebagai berikut:

$$
P=\frac{\sum \text { Siswa.yang.tuntas.belajar }}{\sum \text { Siswa }} \times 100 \%
$$

\section{Hasil}

Data penelitian yang diperoleh berupa hasil uji coba item butir soal, data observasi berupa pengamatan pengelolaan pembelajaran kooperatif model jigsaw dan pengamatan aktivitas siswa dan guru pada akhir pembelajaran, dan data tes formatif siswa pada setiap siklus. Data hasil uji coba item butir soal digunakan untuk mendapatkan tes yang betul-betul mewakili apa yang diinginkan. Data ini selanjutnya dianalisis tingkat validitas, reliabilitas, taraf kesukaran, dan daya pembeda.

Data lembar observasi diambil dari dua pengamatan yaitu data pengamatan pengelolaan pembelajaran kooperatif model jigsaw yang digunakan untuk mengetahui pengaruh penerapan model pembelajaran kooperatif model jigsaw dalam meningkatkan prestasi belajar siswa dan data pengamatan aktivitas siswa dan guru. Data tes formatif untuk mengetahui peningkatan prestasi belajar siswa setelah diterapkan pembelajaran kooperatif model jigsaw.

\section{Analisis Item Butir Soal}

Sebelum melaksanakan pengambilan data melalui instrument penelitian berupa tes dan mendapatkan tes yang baik, maka data tes tersebut diuji dan dianalisis. Uji coba dilakukan pada siswa di luar sasaran penelitian. Analisis tes yang dilakukan meliputi: 
1. Validitas

Validitas butir soal dimaksudkan untuk mengetahui kelayakan tes sehingga dapat digunakan sebagai instrument dalam penelitian ini. Dari perhitungan 5 soal diperoleh 1 soal tidak valid dan 4 soal valid. Hasil dari validits soal-soal dirangkum dalam tabel di bawah ini.

Tabel 1 Soal Valid dan Tidak Valid Tes Formatif Siswa

\begin{tabular}{|l|l|}
\hline Soal Valid & Soal Tidak Valid \\
\hline $1,2,4,5$ & 3 \\
\hline
\end{tabular}

2. Reliabilitas

Soal-soal yang telah memenuhi syarat validitas diuji reliabilitasnya. Dari hasil perhitungan diperoleh koefisien reliabilitas $r_{11}$ sebesar 0, 57. Harga ini lebih besar dari harga $\mathrm{r}$ product moment. Untuk jumlah siswa $(\mathrm{N}=$ 29) dengan $r(95 \%)=0,374$. Dengan demikian soal-soal tes yang digunakan telah memenuhi syarat reliabilitas.

3. Taraf Kesukaran (P)

Taraf kesukaran digunakan untuk mengetahui tingkat kesukaran soal. Hasil analisis menunjukkan dari 5 soal yang diuji terdapat:

- 0 soal mudah

- 5 soal sedang

- 0 soal sukar

4. Daya Pembeda

Analisis daya pembeda dilakukan untuk mengetahui kemampuan soal dalam membedakan siswa yang berkemampuan tinggi dengan siswa yang berkemampuan rendah. Dari hasil analisis daya pembeda diperoleh soal yang berkteriteria jelek sebanyak 1 soal, berkriteria cukup 3 soal, berkriteria baik 1 soal. Dengan demikian soal-soal tes yang digunakan telah memenuhi syara-syarat validitas, reliabilitas, taraf kesukaran, dan

Siklus I daya pembeda.

\section{Tahap Perencanaan}

Pada tahap ini peneliti mempersiapkan perangkat pembelajaran yang terdiri dari rencana pelajaran 1 , soal tes formatif 1 dan alat-alat pengajaran yang mendukung.

\section{Tahap Pelaksanaan (Action)}

Pelaksanaan kegiatan belajar mengajar untuk siklus I dilaksanakan pada tanggal 20 Februari 2018 di Kelas XI IPS 1 dengan jumlah siswa 29 siswa. Dalam hal ini peneliti bertindak sebagai guru. Adapun proses belajar mengajar mengacu pada rencana pelajaran yang telah dipersiapkan. Pengamatan (observasi) dilaksanakan bersamaan dengan pelaksaaan belajar mengajar, guru membagi siswa menjadi kelompok asal dan kelompok ahli, menyajikan materi pembelajaran, setiap kelompok diberi materi diskusi, guru mengarahkan siswa dalam berdiskusi kelompok, lalu siswa diberikan kesempatan presentasi, dan menanggapi terhadap tanggapan kelompok lain. 
Pada akhir proses belajar mengajar siswa diberi tes formatif 1 dengan tujuan untuk mengetahui tingkat keberhasilan siswa dalam proses belajar mengajar yang telah dilakukan. Adapun data hasil penelitian pada siklus I adalah sebagai berikut:

Tabel 2. Nilai Tes Formatif Pada Siklus I tanggal 6 februari 2018

\begin{tabular}{|c|c|c|c|c|c|c|c|}
\hline \multirow{2}{*}{ No. Urut } & \multirow{2}{*}{ Nilai } & \multicolumn{2}{|c|}{ Keterangan } & \multirow{2}{*}{ No. Urut } & \multirow{2}{*}{ Nilai } & \multicolumn{2}{|c|}{ Keterangan } \\
\hline & & $\mathrm{T}$ & TT & & & $\mathrm{T}$ & TT \\
\hline 1 & 60 & & $\sqrt{ }$ & 15 & 60 & & $\sqrt{ }$ \\
\hline 2 & 50 & & $\sqrt{ }$ & 16 & 80 & $\sqrt{ }$ & \\
\hline 3 & 80 & $\sqrt{ }$ & & 17 & 80 & $\sqrt{ }$ & \\
\hline 4 & 78 & $\sqrt{ }$ & & 18 & 80 & $\sqrt{ }$ & \\
\hline 5 & 60 & & $\sqrt{ }$ & 19 & 76 & $\sqrt{ }$ & \\
\hline 6 & 80 & $\sqrt{ }$ & & 20 & 76 & $\sqrt{ }$ & \\
\hline 7 & 50 & & $\sqrt{ }$ & 21 & 76 & $\sqrt{ }$ & \\
\hline 8 & 79 & $\sqrt{ }$ & & 22 & 76 & $\sqrt{ }$ & \\
\hline 9 & 80 & $\sqrt{ }$ & & 23 & 60 & & $\sqrt{ }$ \\
\hline 10 & 50 & & $\sqrt{ }$ & 24 & 80 & $\sqrt{ }$ & \\
\hline 11 & 60 & & $\sqrt{ }$ & 25 & 76 & $\sqrt{ }$ & \\
\hline 12 & 76 & $\sqrt{ }$ & & 26 & 60 & & $\sqrt{ }$ \\
\hline 13 & 80 & $\sqrt{ }$ & & 27 & 77 & $\sqrt{ }$ & \\
\hline \multirow[t]{2}{*}{14} & 79 & $\sqrt{ }$ & & 28 & 80 & $\sqrt{ }$ & \\
\hline & & & & 29 & 80 & $\sqrt{ }$ & \\
\hline Jumlah & 946 & 8 & 6 & Jumlah & 1117 & 12 & 3 \\
\hline \multicolumn{8}{|c|}{$\begin{array}{l}\text { Jumlah Skor Maksimal Ideal } 2900 \\
\text { Jumlah Skor Tercapai } 2063 \\
\text { Rata-Rata Skor Tercapai } 71,137\end{array}$} \\
\hline
\end{tabular}

Keterangan: $\mathrm{T}$

TT

Jumlah siswa yang tuntas

Jumlah siswa yang belum tuntas

Klasikal
: Tuntas

: Tidak Tuntas

$: 20$

$: 9$

: tuntas

Tabel 3. Rekapitulasi Hasil Tes Formatif Siswa Pada Siklus I

\begin{tabular}{|l|l|l|}
\hline No & Uraian & Hasil Siklus I \\
\hline 1 & Nilai rata-rata tes formatif & 71,137 \\
2 & Jumlah siswa yang tuntas belajar & 20 \\
3 & Persentase ketuntasan belajar & 60,71 \\
\hline
\end{tabular}

Dari tabel di atas dapat dijelaskan bahwa dengan menerapkan pembelajaran kooperatif model jigsaw diperoleh nilai rata-rata prestasi belajar siswa adalah 71,137 dan ketuntasan belajar mencapai $60,71 \%$ atau ada 20 siswa dari 29 siswa sudah tuntas belajar. Hasil tersebut menunjukkan bahwa pada siklus pertama secara klasikal siswa belum tuntas belajar, karena siswa yang memperoleh nilai $\geq$ 65 hanya sebesar 60,71\% lebih kecil dari persentase ketuntasan yang dikehendaki 
yaitu sebesar $85 \%$. Hal ini disebabkan karena siswa masih baru dan asing terhadap metode baru yang diterapkan dalam proses belajar mengajar.

\section{Pengamatan (Observasi)}

a. Guru mengamati kegiatan belajar siswa

b. Guru mengamati keaktifan siswa dalam kegiatan belajar

c. Guru mengamati kemampuan kerjasama siswa dalam diskusi kelompok

\section{Refleksi}

Dalam pelaksanaan kegiatan belajar mengajar diperoleh informasi dari hasil pengamatan sebagai berikut:

1) Guru kurang baik dalam memotivasi siswa dan dalam menyampaikan tujuan pembelajaran

2) Guru kurang baik dalam pengelolaan waktu

\section{Revisi}

3) Siswa kurang begitu antusias selama pembelajaran berlangsung.

Pelaksanaan kegiatan belajar mengajar pada siklus I ini masih terdapat kekurangan, sehingga perlu adanya refisi untuk dilakukan pada siklus berikutnya.

1) Guru perlu lebih terampil dalam memotivasi siswa dan lebih jelas dalam menyampaikan tujuan pembelajaran. Dimana siswa diajak untuk terlibat langsung dalam setiap kegiatan yang akan dilakukan.

2) Guru perlu mendistribusikan waktu secara baik dengan menambahkan informasi-informasi yang dirasa perlu dan memberi catatan

3) Guru harus lebih terampil dan bersemangat dalam memotivasi siswa sehingga siswa bisa lebih antusias.

\section{Siklus II}

\section{Tahap Perencanaan}

Pada tahap ini peneliti mempersiapkan perangkat pembelajaran yang terdiri dari rencana pelajaran 2, soal tes formatif II dan alat-alat pengajaran yang mendukung.

\section{Tahap Pelaksanaan}

Pelaksanaan kegiatan belajar mengajar untuk siklus II dilaksanakan pada tanggal 13 Maret 2018 di Kelas XI IPS 1 dengan jumlah siswa 28 siswa. Dalam hal ini peneliti bertindak sebagai guru. Adapun proses belajar mengajar mengacu pada rencana pelajaran dengan memperhatikan revisi pada siklus I, sehingga kesalahan atau kekurangan pada siklus I tidak terulang lagi pada siklus II. Pengamatan (observasi) dilaksanakan bersamaan dengan pelaksanaan belajar mengajar.

Pada akhir proses belajar mengajar siswa diberi tes formatif 2 dengan tujuan untuk mengetahui tingkat keberhasilan siswa dalam proses belajar mengajar yang telah dilakukan. Instrument yang digunakan adalah tes formatif II. Adapun data hasil penelitian pada siklus II adalah sebagai berikut. 
Tabel 4. Nilai Tes Formatif Pada Siklus II tanggal 13 maret 2018

\begin{tabular}{|c|c|c|c|c|c|c|c|}
\hline \multirow{2}{*}{$\begin{array}{l}\text { No. } \\
\text { Urut }\end{array}$} & \multirow{2}{*}{ Nilai } & \multicolumn{2}{|c|}{ Keterangan } & \multirow{2}{*}{$\begin{array}{l}\text { No. } \\
\text { Urut }\end{array}$} & \multirow{2}{*}{ Nilai } & \multicolumn{2}{|c|}{ Keterangan } \\
\hline & & $\mathrm{T}$ & TT & & & $\mathrm{T}$ & TT \\
\hline 1 & 80 & $\sqrt{ }$ & & 15 & 78 & & \\
\hline 2 & 78 & & & 16 & 60 & & $\sqrt{ }$ \\
\hline 3 & 90 & $\sqrt{ }$ & & 17 & 80 & $\sqrt{ }$ & \\
\hline 4 & 80 & $\sqrt{ }$ & & 18 & 78 & $\sqrt{ }$ & \\
\hline 5 & 78 & $\sqrt{ }$ & & 19 & 79 & $\sqrt{ }$ & \\
\hline 6 & 78 & & & 20 & 78 & $\sqrt{ }$ & \\
\hline 7 & 80 & $\sqrt{ }$ & & 21 & 60 & & $\sqrt{ }$ \\
\hline 8 & 60 & & $\sqrt{ }$ & 22 & 90 & 2 & \\
\hline 9 & 76 & $\sqrt{ }$ & & 23 & 80 & $\sqrt{ }$ & \\
\hline 10 & 80 & $\sqrt{ }$ & & 24 & 60 & & $\sqrt{ }$ \\
\hline 11 & 80 & $\sqrt{ }$ & & 25 & 80 & $\sqrt{ }$ & \\
\hline 12 & 76 & $\sqrt{ }$ & & 26 & 60 & & $\sqrt{ }$ \\
\hline 13 & 78 & $\sqrt{ }$ & & 27 & 100 & $\sqrt{ }$ & \\
\hline 14 & 79 & $\sqrt{ }$ & & 28 & 76 & $\sqrt{ }$ & \\
\hline Jumlah & 1092 & 13 & 1 & Jumlah & 1131 & 10 & 4 \\
\hline \multicolumn{8}{|c|}{ Jumlah Skor Maksimal Ideal 2800} \\
\hline \multicolumn{8}{|c|}{ Jumlah Skor Tercapai 2133} \\
\hline \multicolumn{8}{|c|}{ Rata-Rata Skor Tercapai 76,17 } \\
\hline
\end{tabular}

$\begin{array}{lll}\text { Keterangan: } & \text { T } & \text { : Tuntas } \\ & \text { TT } & : \text { Tidak Tuntas } \\ & \text { Jumlah siswa yang tuntas } & : 23 \\ \text { Jumlah siswa yang belum tuntas } & : 5 \\ \text { Klasikal } & : \text { tuntas }\end{array}$


Tabel 5. Hasil Tes Formatif Siswa Pada Siklus II tanggal 13 maret 2018

\begin{tabular}{|l|l|l|}
\hline No & Uraian & Hasil Siklus II \\
\hline 1 & Nilai rata-rata tes formatif & 76,17 \\
2 & Jumlah siswa yang tuntas belajar & 23 \\
3 & Persentase ketuntasan belajar & 85,00 \\
\hline
\end{tabular}

Dari tabel di atas diperoleh nilai rata-rata prestasi belajar siswa adalah 76.17 dan ketuntasan belajar mencapai 85,00\% atau ada 23 siswa dari 28 siswa sudah tuntas belajar. Hasil ini menunjukkan bahwa pada siklus II ini ketuntasan belajar secara klasikal telah mengalami peningkatan sedikit lebih baik dari siklus I. Adanya peningkatan hasil belajar siswa ini karena siswa mambantu siswa yang kurang mampu dalam mata pelajaran yang mereka pelajari. Disamping itu adanya kemampuan guru yang mulai meningkat dalam prose belajar mengajar.

Pengamatan (Observasi)

Dalam pelaksanaan kegiatan belajar diperoleh informasi dari hasil pengamatan sebagai berikut:

1) Memotivasi siswa

2) Membimbing siswa merumuskan kesimpulan/menemukan konsep

3) Pengelolaan waktu

\section{Revisi Rancangan}

Pelaksanaan kegiatan belajar pada siklus II ini masih terdapat kekurangankekurangan. Maka perlu adanya revisi untuk dilaksanakan pada siklus II antara lain:

1) Guru dalam memotivasi siswa hendaknya dapat membuat siswa lebih termotivasi selama proses belajar mengajar berlangsung.

2) Guru harus lebih dekat dengan siswa sehingga tidak ada perasaan takut dalam diri siswa baik untuk mengemukakan pendapat atau bertanya.

3) Guru harus lebih sabar dalam membimbing siswa merumuskan kesimpulan/menemukan konsep.

4) Guru harus mendistribusikan waktu secara baik sehingga kegiatan pembelajaran dapat berjalan sesuai dengan yang diharapkan.

5) Guru sebaiknya menambah lebih banyak contoh soal dan memberi soalsoal latihan pada siswa untuk dikerjakan pada setiap kegiatan belajar mengajar.

\section{Refleksi}

Pada tahap ini akah dikaji apa yang telah terlaksana dengan baik maupun yang masih kurang baik dalam proses belajar mengajar dengan penerapan pembelajaran kooperatif model jigsaw. Dari data-data yang telah diperoleh dapat duraikan sebagai berikut:

1. Selama proses belajar mengajar guru telah melaksanakan semua pembelajaran dengan baik. Meskipun ada beberapa aspek yang belum sempurna, tetapi persentase pelaksanaannya untuk masing-masing aspek cukup besar. 
2. Berdasarkan data hasil pengamatan diketahui bahwa siswa aktif selama proses belajar berlangsung.

3. Kekurangan pada siklus-siklus sebelumnya sudah mengalami perbaikan dan peningkatan sehingga menjadi lebih baik.

4. Hasil belajar siswa pada siklus II mencapai ketuntasan.

\section{Revisi Pelaksanaan}

Pada siklus II guru telah menerapkan pembelajaran kooperatif model jigsaw dengan baik dan dilihat dari aktivitas siswa serta hasil belajar siswa pelaksanaan proses belajar mengajar sudah berjalan dengan baik. Maka tidak diperlukan revisi terlalu banyak, tetapi yang perlu diperhatikan untuk tindakah selanjutnya adalah memaksimalkan dan mempertahankan apa yang telah ada dengan tujuan agar pada pelaksanaan proses belajar mengajar selanjutnya penerapan pembelajaran kooperatif model jigsaw dapat meningkatkan proses belajar mengajar sehingga tujuan pembelajaran dapat tercapai.

\section{Pembahasan}

\section{Ketuntasan Hasil Belajar Siswa}

Melalui hasil peneilitian ini menunjukkan bahwa pembelajaran kooperatif model jigsaw memiliki dampak positif dalam meningkatkan prestasi belajar siswa. Hal ini dapat dilihat dari semakin mantapnya pemahaman dan penguasaan siswa terhadap materi yang telah disampaikan guru selama ini (ketuntasan belajar meningkat dari siklus I, dan II) yaitu masing-masing 71,00\%, dan $85 \%$. Pada siklus II ketuntasan belajar siswa secara klasikal telah tercapai.

\section{Kemampuan Guru Dalam Mengelola Pembelajaran}

Berdasarkan analisis data, diperoleh aktivitas siswa dalam proses pembelajaran kooperatif model jigsaw dalam setiap siklus mengalami peningkatan. Hal ini berdampak positif dalam peningkatan prestasi belajar siswa, yaitu dapat ditunjukkan dengan meningkatnya nilai rata-rata siswa pada setiap siklus yang terus mengalami peningkatan.

\section{Aktivitas Guru Dan Siswa Dalam Pembelajaran}

Berdasarkan analisis data, diperoleh aktivitas siswa dalam proses pembelajaran sejarah Indonesia pada masa praaksara yang paling dominan adalah, mendengarkan/memperhatikan penjelasan guru, dan diskusi antar siswa/antara siswa dengan guru. Jadi dapat dikatakan bahwa aktivitas siswa dapat dikategorikan aktif.

Sedangkan untuk aktivitas guru selama pembelajaran telah melaksanakan langkah-langkah pembelajaran kooperatif model jigsaw dengan baik. Hal ini terlihat dari aktivitas guru yang muncul di antaranya aktivitas membimbing dan mengamati siswa dalam mengerjakan kegiatan, menjelaskan/melatih menggunakan alat, memberi umpan balik/evaluasi/tanya jawab dimana prosentase untuk aktivitas di atas cukup besar.

\section{Kesimpulan}

Dari hasil kegiatan pembelajaran yang telah dilakukan selama dua siklus, dan berdasarkan seluruh pembahasan serta analisis yang telah dilakukan dapat disimpulkan sebagai berikut:

1. Penerapan pembelajaran kooperatif model jigsaw memiliki dapat meningkatkan aktivitas belajar mengajar yang dapat berpengaruh 
terhadap hasil belajar siswa maupun kinerja guru dalam melaksanakan kegiatan pembelajaran yang efektif dan efisien.

2. Hasil penguasaan siswa terhadap materi pembelajaran menunjukkan adanya peningkatan dengan nilai perolehan rata-rata $64 \%$ pada ulangan sebelum melaksanakan tipe jigsaw, setelah menggunakan tipe jigsaw yang ditandai dengan peningkatan ketuntasan belajar siswa dalam setiap siklus, yaitu siklus I (71\%), siklus II (85\%)

3. Penerapan pembelajaran kooperatif model jigsaw mempunyai pengaruh positif, yaitu dapat meningkatkan motivasi belajar siswa untuk mempelajari kembali materi pelajaran yang telah diterima, hal ini ditunjukan dengan antusias siswa yang menyatakan bahwa siswa tertarik dan berminat dengan pembelajaran kooperatif model jigsaw sehingga mereka menjadi termotivasi untuk belajar.

4. Pembelajaran kooperatif model jigsaw memiliki dampak positif terhadap kerjasama antara siswa, hal ini ditunjukkan adanya tanggung jawab dalam kelompok dimana siswa yang lebih mampu mengajari temannya yang kurang mampu.

5. Pembelajaran kooperatif jigsaw dapat membuat pembelajaran sejarah Saran menjadi menyenangkan.

Dengan demikian bahwa pembelajaran kooperatif tipe jigsaw dapat meningkatkan aktivitas dan hasil belajar pada diri siswa baik secara individual maupun secara kelompok pada mata pelajaran sejarah. Oleh karena itu kami menyampaikan saran-saran sebagai berikut:

1. Dalam setiap kegiatan pembelajaran seyogyanya guru menggunakan pembelajaran kooperetif learning tipe jigsaw sebagai suatu alternative untuk meningkatkan aktivitas dan hasil belajar siswa khususnya dalam pembelajaran sejarah.

2. Untuk melaksanakan pembelajaran kooperatif model jigsaw memerlukan persiapan yang cukup matang, sehingga guru harus mempu menentukan atau memilih topik yang benar-benar bisa diterapkan dengan pembelajaran kooperatif model jigsaw dalam proses belajar mengajar sehingga diperoleh hasil yang optimal.

3. Dalam rangka meningkatkan prestasi belajar siswa, guru hendaknya lebih sering melatih siswa dengan berbagai metode pengajaran yang sesuai, walau dalam taraf yang sederhana, dimana siswa nantinya dapat menemukan pengetahuan baru, memperoleh konsep dan keterampilan, sehingga siswa berhasil atau mampu memecahkan masalah-masalah yang dihadapinya.

4. Perlu adanya penelitian yang lebih lanjut, karena hasil penelitian ini hanya dilakukan di kelas X IPS 5

5. Untuk penelitian yang serupa hendaknya dilakukan perbaikan-perbaikan agar diperoleh hasil yang lebih baik. 
Novrita Suryani

\section{Daftar Rujukan}

Abdurrahman, M., \& Bintoro, Totok. 2000. Memahamai dan menangani siswa dengan problema dalam belajar: pedoman guru. Jakarta: Proyek Peningkatan Mutu SLTP, Direktorat Pendidikan Menengah Umum. Direktorat Jenderal Dasar dan Menengah. Departemen Pendidikan Nasional.

Anita, Lie. 2010. Cooperative learning mempraktekkan cooperative learning di ruang-ruang kelas. Jakarta: PT. Grasindo Widia Sarana Indonesia.2010

Arikunto, Suharsimi. 1999. Prosedur Penelitian Suatu Pendekatan Praktek. Jakarta: Rineksa Cipta.

Marimba. A.D. 1978. Psikologi Perkembangan. Jakarta: Aksara Baru.

Nawawi, Hadari. 1981. Administrasi Pendidikan. Jakarta: Gunung Agung.

Poerwodarminto. 1991. Kamus Umum Bahasa Indonesia. Jakarta: Bina Ilmu.

Susanto, Ahmad. 2013. Teori belajar pembembelajaran di sekolah dasar. Jakarta: Kencana.

Sumaryono, Agus. 2019. Meningkatkan hasil belajar sejarah pokok bahasan peradaban Indonesia dan dunia melauai pembelajaran kooperatif modelnumbered head together pada siswa kelasX-3 Semester II SMA di akases dari tyovillage.blogspot. com. pada hari Minggu 20 Januari 2019 